\title{
Level of Economic Prosperity, Social Status and Comfortable Living of Migrant Workers in Tulungagung District, Indonesia
}

\author{
Budijanto, PhD \\ Faculty of Social Science, State University of Malang, 65145 East Java, Indonesia \\ budijanto19@yahoo.co.id \\ Wan Ibrahim Wan Ahmad, PhD \\ School of Social Development, Universiti Utara Malaysia, 06010 Sintok, Kedah, Malaysia \\ wiwa@uum.edu.my \\ I Komang Astina, PhD \\ Faculty of Social Science, State University of Malang, 65145 East Java, Indonesia \\ k_astina@yahoo.com
}

Doi:10.5901/mjss.2015.v6n3s2p282

\section{Abstract}

Indonesia provides a particularly intriguing context for a study of international migration of workforce. Most of the villages in Indonesia have been a sender of labor abroad. Remittance from migrant workers working overseas undoubtedly has a positive impact on socioeconomic development of local community in the country of origin. This research has conducted to get a general picture on the level of value-expectancy of Indonesian migrant workers working overseas, particularly in terms of their economic prosperity, level of comfortable living, as well as social status achieved in community. The research, which is using survey design, has been conducted at Tulungagung district, East Java, Indonesia. To meet this objective, 250 Indonesian migrant workers working overseas which are on their leave at the study area have been chosen for interviews. Results of the study show that remittance inflows have a significant impact on the level of economic prosperity, comfortable living, as well as social status achieved in community. Thus, it is not wrong when the main purpose of doing international migration is to improve the economic condition of the family.

Keywords: Remittance; Migration; Value-expectancy; Migrant Workers

\section{Introduction}

Indonesia is a country that has a very large number of populations. According to the latest census, the populations of Indonesia in 2005 were about 232370 million of people (BPS., 2006). Unemployment and underemployment are critical disturbing the progress of development in Indonesia for decades. Employment creation, particularly in the formal sector is limited to accommodate the availability of labor supply. Those who cannot be absorbed in the formal sector have to work either in the informal sector or doing international migration. $70 \%$ of the workforce in Indonesia was estimated to be engaged in informal employment, mostly in the agriculture sector (Firdausy, 2000; Rusman Hariawan, 2011). While it is perceived the informal sector contributes significantly to Indonesia's economy, particularly in terms of employment, by providing economic opportunities to those displaced from or who cannot be absorbed by the formal sector (Rusman Hariawan, 2011), doing international migration to be migrant workers in the efforts of improving the level of life of the families is still to be an important agenda for rural community in Indonesia. International migration of the workforce has been extensive for decades in Indonesia contributing to continuing development in certain parts of rural areas.

\section{Objective of the Study}

The present paper discusses the level of economic prosperity, social status and comfortable living of migrant workers in Tulungagung district, Indonesia. In particular, it analyzes: (1) level of economic prosperity, (2) level of social status, and (3) level of comfortable living of migrants workers from Tulungfagung district, East Java, Indonesia. 


\section{Literature Review}

Migrant worker is a term used to refer to migrant for employment. Article 11, ILO Convention on Migration for Employment 1949, (No. 97) states that migrant for employment means a person who migrates from one country to another with a view to being employed otherwise than on his own account and includes any person regularly admitted as a migrant for employment (Piyasiri Wikramasekera, 2002). The pace of international migration has playing an important role in shaping and reshaping demographic features and determining the pace of economic growth and development of many countries (Institute of Policy Studies of Sri Lanka, 2013). United Nations estimates the number of international migrants stood at 214 million in 2010, representing 3 percent of the world's population (Institute of Policy Studies of Sri Lanka, 2013), and if the migrants continues to grow at the same pace, it is estimated that the stock of migrants will increase to 405 million by 2050 (IOM, 2010; Institute of Policy Studies of Sri Lanka, 2013). At the global level, in 2013, there are approximately 232 million people live and work outside the country of his birth, and $48 \%$ of the total migrant is women. $51 \%$ of the total international migrant stock is found in 10 countries, i.e. the United States (46 million), the Russian Union (11 million), German (10 million), Saudi Arabia (9 million), and the United Arab Emirates and the United Kingdom, 8 million respectively. In the relatively small number there is in France, Canada, Australia and Spain (United Nations, 2013). Between 1990 and the end of 2013, the international migrant increased by more than 77 million or 50\% and most of the increase occurred between 2000 and 2010. Between 2000 and 2010 a total of 4.6 million migrant increased every year compared to an average of only around two million a year for the period 1990-2000 and 3.6 million for the period 2010-2013 (United Nations, 2013).

One question behind the process of migration is why migration occurred and how it can continue overtime? (Schmitter-Heisler, 2000; Sonja, 2008). Research in the area of international migration covers a wide range of scope (Farwick, 2009), and it is one of the popular areas of research in social sciences, including in the study of globalization, sociology, geography, demographics, history of the world and political economy (Lee Wai Yee, 2000), and they are mainly associated with motive, direction or distance, including decision-making. This is particularly true as the most fundamental reason for migration is a belief that the move will result in some advantage, particularly in terms of monetary the family does not presently enjoy (Harries and Norris, 1986). This shows that migration crossing national borders is increasingly seen as an important component of social and economic development of a country. An increasing number of this migration is driven by economic inequality between countries as a result of the impact of wealth and imbalanced in economic development. That is why millions of people from various parts of the world to move across international borders in their efforts to improve the level of life of their families. As the main motive of the people doing the international migration is to improve the level of living of family members, remittance plays an important role of international migrant.

Over the past few decades remittances have emerged as the second largest sources of external funding for developing countries (Remirez, Dominguiz, and Morais, 2005). Remittances are the most visible and direct benefit for migrants and their families (International Organization for Migration, 2008). Remittance is basically a cross border sending of money from migrants overseas to families at their home country. With these remittances, it is hoped that the migrants may meet expected changes towards improving the social and economic life of their families (Goma, 1993: 407). Indonesia provides a particularly intriguing context for a study of international migration of workforce. The aim of this paper is to analyze the level of economic prosperity, social status, and level of comfortable living of Indonesian migrant workers who are crossing national boundaries to works abroad. There are several models that have been developed to explain the process behind the migration. De Jong and Fawcett (1981) has proposed a model called the valueexpectancy model in analyzing the decision made behind migration process. This model highlights seven motives as the main reasons behind migration.

\section{Materials and Method}

Most of the villages in Indonesia have been a sender of labor abroad. Research in this paper is conducted using survey design, particularly explanatory approach. Explanatory research is used as a study design because it is seen suitable to be used when a problem has been identified but our understanding of it is limited (Yegidis and Weinbach, 2002). The focus of this research is on the migrants living in Tulungagung district, East Java, Indonesia. Tulungagung district has three areas that are physically and economically distinct, i.e. agricultural area, rice cultivation area, and mixed area. One area in a district which has a biggest number of migrants working abroad is selected. Then, for every area the village which has a highest number of migrant workers working abroad was selected as a study area. The number of respondents in this study is 250 migrants. They are migrants who are now working abroad who happen to come home on leave in the study area. Data collected through face-to-face interviews and analyzed descriptively. 


\section{Results and Discussion}

Indonesia, with a GNP per capita in 2005 of USD 1, 280 according to the World Bank, remains one of the poorer nations in Southeast Asia (Hugo, 2007). As stated by Hugo (2007), Indonesia is a quintessential labor-surplus nation, and at the end of 2006, an estimated 11 percent of Indonesian workers (11.6 million) were unemployed. The district face the same situation, and for the past two decades has been a primarily substance agriculture, pre-modern area, but in recent years have turned to a 'highly' developed, modernized, and improved in the village level of living because of remittance from migrant workers.

By looking at the number of remittance received by the district, it strongly support that the international labor migration in Tulungagung district has proved to have made a miracle to the changes of community development. In recent years the district has been transformed into townships with a wide range of community economic activities, with structured and luxury housing programs. As indicated, the main purpose of this study is to provide a general picture of the level of achievement of Indonesian migrant workers working overseas. As highlights by researchers in the field of international migration, the main objective of people crossing an international boundary is to improve their family level of living. This improvement, among other things, is reflected in level of economic prosperity, comfortable living, and social status achieved. Thus, the results of the study will be discussed according to respondents' profile, level of economics prosperity, level of social status, and level of comfortable living of migrant workers.

\subsection{Profile of Respondents}

It is important to note that most of the respondents who become migrant workers working overseas have been from rural areas. They are moving across international borders to improve the level of life of their families. Thus, these migrant workers are mainly do not have a suitable job at their village, have a low level of education, and more importantly, they also have a low level of standard of living. Results of the study show that most of migrants are women (62.2\%) aged 39 years and less (74.8\%). Not many are single before doing an international migration. Most of them (84.4\%) are married. In terms of education, most of the respondents are high school educated. Many of these respondents are not working. Those who work are working as peasants, or labor whether in an agricultural or in constructions setting. They are from peasant family who are largely categorized as low-income family, do not have a cultivated land, and do not having life skills that can be used as means of living. Because they do not have any suitable jobs, they do not have enough income, and because of these, they decided to migrate.

\subsection{Level of Economic Prosperity}

Prosperity is used to mean the condition of being prosperous, especially in financial respects. Undoubtedly, one of the main reasons behind the migration of migrant workers is economic prosperity of the family left in the country of origin. Migrant families are said to be prosperous when all material needs can be met, and the level of economic prosperity can be measured from the number of goods and services they produced. To measure the level of prosperity, we use five items, i.e. (1) having a high income, (2) having a secured income, (3) having economic security in old age, (4) able to fulfill basic needs, and (5) having social and economic security in in life. The distribution of respondents based on the level of prosperity is shown through Table 1.

Table 1: Level of Economic Prosperity

\begin{tabular}{|c|c|c|}
\hline Level of Economic Prosperity & Number & Percentage \\
\hline Low & 198 & 79.2 \\
\hline Moderate & 38 & 15.2 \\
\hline High & 14 & 5.6 \\
\hline Number & 250 & 100.0 \\
\hline
\end{tabular}

Based on Table 1 it can be explained the highest percentage of respondents is respondents who admitted that they have achieved low level of prosperity (79.2\%). Responden who achieved the moderate level of prosperity is $15.2 \%$, while responden who achieved the high level of prosperity is $5.6 \%$. 


\subsection{Level of Social Status}

Social status is simply to mean the position of a person or a group of individuals who have a similar position within a community or society. Although the position or the status can also be achieved by inherited position, social status in this paper is the status achieved by one's own achievement. Everyone tends to perceive status in the community is an important factor in life in relation to others. Many factors combined together to affect the status of individuals in the community. Higher social status generally is linked to the level of income. The inequality in income creates the status differences. By the status in this paper we mean as the social status which is a set of rights and obligations owned by someone in the community. People who have high social status will be placed a higher level in the structure of society compared to those who have low social status. According to De Jong and Fawcett (1981), status differences will be achieved when the family; (1) having an authoritative jobs, (2) respected within the community, (3) having good education, and (4) having power and influence. The status is depicted in Table 2. The largest percentage is respondents with lower status (53.2\%.) The respondents who have achieved the moderate level are $24.0 \%$, while who have achieved a high level of status are $22.8 \%$.

Table 2: Level of Social Status

\begin{tabular}{|c|c|c|}
\hline Level of Social Status & Number & Percentage \\
\hline Low & 133 & 53.2 \\
\hline Moderate & 60 & 24.0 \\
\hline High & 57 & 22.8 \\
\hline Number & 250 & 100.0 \\
\hline
\end{tabular}

\subsection{Level of Comfortable Living}

Migration is a powerful force of social change, and it provides migrants with significant opportunities to progress (Alonso, 2011). Among the main objectives of doing international migration is to achieve a comfortable living of the family. Comfort is a pleasurable ease, free from pain, or free from stress, anxiety or anything in relation to unpleasant in family life. In other words, comfort, or comfortable living is the condition of mind that express satisfaction with living condition whether physiologically, or psychologically. Migrant workers generally will take every step to ensure their life as well as their family life left in their country comfortable. For them comfortable living of their family in their country is particularly important. The comfort levels of the migrant workers depend on a number of particular external factors.

To measure the comfort level of the migrant workers, this study uses indicators of comfortable living according to De Jong and Fawcett (1981) include; (1) having light jobs, (2) staying in a pleasant community, (3) having a lot of free time, and (4) having a comfortable home. The distribution of respondents based on the level of a comfortable living is depicted in Table 3. From the table it can be explained the highest percentage of respondents is respondents who perceived they have achieved low level of comfortable living (42.4\%). The percentage of respondent who have achieved high level of a comfortable living is also quite high (31.3\%), while respondent who have achieved the moderate level of a comfortable living is $26.1 \%$. Thus, migrant workers have already had a light job; living in a pleasant community, having a lot of free time, as well as have a comfortable home. Around $57.4 \%$ of them have achieved these aspects.

Table 3: Level of Comfortable Living

\begin{tabular}{|c|c|c|}
\hline Level of Comfortable & Number & Percentage \\
\hline Low & 106 & 42.4 \\
\hline Moderate & 65 & 26.0 \\
\hline High & 79 & 31.6 \\
\hline Number & 250 & 100.0 \\
\hline
\end{tabular}

Thus, from the table as depicted above, the majority of the respondents are still do not meet the objectives of the international migration they made. Their choice to do an international migration some years back was to contribute to the social mobility of the family. They took a choice not to spend their whole lives in their native village, but to move out in search of security and a better livelihood. This is in line with what neo-economic theory suggests that the main cause of migration is efforts to maximize individual income by moving from a low-wage to a high-wage economy (Borjas, 1989). 
They feel they are still do not fulfill this main objective.

\section{Conclusion}

Migration is always been part of human life. Although there are many reasons behind the migration process, the most obvious cause is the disparity in levels of income, employment and social well-being between differing areas. People decided to do a migration as they seek a better livelihood of their family. This is why in recent years millions of people from various parts of the world are moving across international borders in their efforts to improve the level of living of their families. Economic inequality between countries that has created the imbalanced in wealth and economic development has been an important factor that fueled an increasing number of international migrations. The present paper describes the level of achievement of Indonesian migrant workers in Tulungagung district working abroad that are now currently on their vacation and return to their villages. There are now approximately 3000 migrant from this area working abroad. With the large number of migrants working abroad, they are able to contribute a lot of remittance to the district. That is why the villagers in study area where around two decades ago were very poor, however, in recent years the situation has changed a lot. Results of the study reveal that the migrant workers still do not fully achieved some of their targeted in doing international migration. The level of prosperity, as well as comfort and status in the community are still low. But, one thing for them is working as a migrant worker abroad was able to improve the condition of the economy of their family as a whole.

\section{References}

Alonso, J. A. (2011). International migration and development: A review in light of the crisis. CDP Background Paper No. 11 (E). United Nations: New York: Department of Economic and Social Affairs, Population Division.

Borjas, G. J. (1989). Economic theory and international migration. International Migration Review, Special Silver Anniversary Issue, vol. 23: $457-85$

BPS. (2006). Survey penduduk antarsensus, 2005. Jakarta: Badan Pusat Statistik

De Jong, G. F, \& J. T. Fawcett. (1981). Motivation for migration. An assessment and a value-expectancy research - model, in De long \& Robert W Gardner (eds). Migration decision making, multidiciplinary approach to microlevel studies in developed and developing countries. New York: Pergamon Press.

Farwick, Andreas. (2009). Internal migration: Challenges and perspectives for the research infrastructure. Working Paper Series No. 97. Working Paper Series of the Council for Social and Economic Data, University of Bremen, Germany

Firdausy, C.M. 2000. The Social Impact of Economic Crisis on Employment in Indonesia. Center for Economic and Development Studies-Indonesian Institute of Sciences. Available: www.ismea.org/asialist/Firdausy.html

Goma, Johana Naomi. (1993). Mobilitas tenga kerja Flores Timur ke Sabah dan pengaruhnya terhadap daerah asal: Studi Kasus Desa Neleren, Kecamatan Adomara. Flores Timur. Yogyakarta, UGM.

Harries, K. D \& Norris, R. E. (1986). Human geography: Culture, interaction, and economy. Ohio: Merrill Publising Company

Haug, Sonja. (2008). Migration networks and migration decision-making. Journal of Ethnic and Migration Studies, 34 (4): 585 - 605

Hugo, G. (2007). Indonesia's labor looks abroad. Washington: Migration Policy Institute.

International Organization for Migration. (2008). Situation report on international migration in East and South-East Asia. Bangkok: International Organization for Migration.

Institute of Policy Studies. (2013). Migration profile Sri Lanka. Sri Lanka: IPS.

Lee Wai Yee, Michelle. 2000. Transmigrasi, gender dan identiti: Migran wanita Filipina di Malaysia, dlm Rahimah Abd Aziz \& Mohamed Yusuff Ismail. Masyarakat, budaya dan perubahan. Bangi: Penerbit Universiti Kebangsaan Malaysia.

Piyasiri Wikramasekera. (2002). Asian labour migration: Issues and challenges in an era of globalization. International Migration Papers 57. Geneva: International Labour Office.

Remirez C, Dominguiz M. G, \& Morais, J. M. (2005). Crossing borders: Remittances, gender and development. Santo Domingo: Instraw

Rusman Hariawan, 2011. The informal sector and informal employment in Indonesia. Country Report 2010. Jakarta: Asian Development Bank, BPS, Statistics Indonesia.

Schmitter-Heisler, B. (2000). The sociology of immigration, in Brettell, C.B. and Hollifield, J.F. (eds). Migration theory: Talking across disciplines. New York: Routledge.

Sonja, Haug. (2008). Migration networks and migration decision-making. Journal of Ethnic and Migration Studies, 34:4, 585 - 605.

United Nations. (2013). International Migration Report 2013. New York: Department of Economic and Social Affairs, Population Division.

Yegidis, B. L., \& Weinbach, R. W. (2002). Research methods for social workers (forth ed). Boston: Allyn and Bacon 